\title{
CAN META-STEREOTYPING ACCOUNT FOR UNWARRANTED NEGATIVE RECEPTION OF THE UK TV DOCUMENTARY "THE ROMANIANS ARE COMING"?
}

\author{
DELIA NADOLU \\ Department of Sociology, West University of Timisoara, Romania \\ (C) 2020 Delia Nadolu
}

This is an open access article distributed under the Creative Commons Attribution-NonCommercial-NoDerivs license (http://creativecommons.org/licenses/by-nc-nd/3.0/)

DOI: 10.1515/eras-2020-0003

\begin{abstract}
In February 2015 the UK TV station Channel 4 started screening James Bluemel's series “The Romanians Are Coming", a three-part documentary film about "the lives of poor Romanian people who seek work in Great Britain, seen through the eyes of the British people". This documentary provoked strong opposition from some Romanian politicians and mass media outlets. In the UK the reaction was a contrasting one: sympathy, understanding and compassion. We showed the series to three Romanian university classes in 2017-18 and the students largely had a negative reaction similar to that of those Romanian commentators. A standard content analysis of the film, however, suggests that it gives a positive image of Romanian immigrants in the UK. Despite this, our audiences tended to form a negative perception of the film. We attribute this disparity to the wording of its title activating two classical stereotypes: that Romanians are often Roma, and that poor people are a source of social problems. The film as a whole in fact projects an opposite message, but once these stereotypes have been activated the content is automatically perceived as negative.
\end{abstract}

\section{Keywords}

migrants, Roma, mass-media, stereotype, content analysis

\section{Introduction}

On 17 February 2015 the UK TV station Channel 4 started screening James Bluemel's three-part documentary series "The Romanians Are Coming". According to their published description, the film was about "the lives of poor Romanian people who seek work in Great Britain, seen through the eyes of the British people". This documentary provoked strong opposition from some Romanian politicians and mass media outlets. There was a widespread negative reaction in Romania's national mass media lasting almost a week. The Romanian Embassy in London and the Foreign Ministry in Bucharest expressed public disapproval of the supposed message of the documentary: "The documentary was criticised by the Foreign Affairs Ministry in Bucharest and by Romanian Embassy in in London. By contrast, several Romanian NGOs congratulated the British TV station on this series of documentaries and said that the protests of the Romanian officials were generated by indifference, or hypocrisy about the poverty problem" (ziare.com). A protest demonstration was also staged in London, outside the Channel 4 studios, albeit with only a small number of participants. The film was, however, nominated for Best Documentary Series at the UK 2015 Grierson Awards. 
Is the content really so controversial? Why is opinion divided over this documentary? Has it been correctly appraised? Our research hypothesis was that the public perception of this documentary in Romania was filtered through the influence that the stereotypes attributed to the British film makers exercised on the Romanian receivers. In other words, even though the film has largely sympathetic content, the activation of the stereotypes affects to a significant degree its received sense. Here the main stereotype was probably the belief that poor Romanian people are stigmatised by many people in western Europe as "gypsies". The perception of this stigmatisation is a very complex phenomenon with dramatic consequences in the social space (Goffman 1968, Link\&Pehaln 2001). From a classical perspective, stereotypes are beliefs and representations about the characteristics, attributes, and behaviours of members of certain groups (Hilton\&Von Hippel, 1996: 240).

Thus, one of the major components in the manifestation of this phenomenon is alterity, the presence of "the other" as a group, different, unknown, and potentially dangerous. Research studies have found that stereotypes about out-group members tend to have more negative connotations than those about in-group members. Easy identification of the Other as a group facilitates the development of stereotypes about them (Esses et al., 1993, Bigler\&Liben, 2006, Stangor\&Lange 1994). According to Allport's Intergroup Contact Hypothesis, the positive effects of intergroup contact can occur only in situations in which four conditions are simultaneously met: equal group status, common goals, intergroup cooperation, and the support of authorities, law or custom (Allport 1954). In our case study involving Romanian immigrants in the UK, none of these conditions is unambiguously fulfilled: the difference in status between the Romanian minority depicted and the British majority is very great, their goals are significantly different, intergroup cooperation is limited, and the authorities transmit a dissonant message (both pro and con the immigrants). Furthermore, national-character stereotypes are probably the most inaccurate (Jussim, Crawford and Rubinstein, 2015: 494).

In intergroup contact, communication emerges as a critical factor for cognitive perception and representation of the alter (Ruscher, 1998: 243, Grubb\&Hupp, 1968: 58-59). The influence of the mass media (as authorised voices) on such cases of interpersonal communication is quite strong. It is relatively easy to activate an automatic stereotype through a public communicator (Blair, 2002). One of the most negative consequences of such stereotyping is the so-called stereotype threat, defined as: "When members of a stigmatized group find themselves in a situation where negative stereotypes provide a possible framework for interpreting their behaviour, the risk of being judged in light of those stereotypes can elicit a disruptive state that undermines performance and aspirations in that domain" (Spencer, Logel and Davies, 2016: 415). Thus, a direct and very important consequence is that the members of negatively stereotyped groups are prevented from performing to their full potential (Appel, Kronberger, 2012).

What influencing factors were at work in the case of this documentary "The Romanians Are Coming"? Why did Romanian public figures and the mass media react to it in such a hostile way? Is it perhaps possible that this reaction was rooted in a latent stereotype about the British film makers and the presumed prejudices of their target audience in the minds of the Romanian receivers that distorted their perception of the intended meaning of the film? If so, could this Romanian-held stereotype have actually involved a fear of being stereotyped by others? In search of answers to these questions we carried out a standard content analysis of the entire series and interviewed a sample of one hundred students about their perceptions of the film.

\section{Methods}

Taking as our point of departure the unexpectedly negative reactions to this film in the Romanian mass media (13 newspaper articles and several TV news items, all against the 
documentary), we decided to check directly with a number of groups of students (100 participants from three different academic specialisations - anthropology, sociology and psychology -, as representing educated subjects) about how they had viewed the film and why. Perhaps surprisingly, they displayed similar kinds of resentment of what they took to be the message of the film. They maintained these opinions even when, in the after-viewing discussion, we drew attention to all its positive aspects. We therefore decided to follow up with a classical exploratory content analysis of the film, scene by scene, and to evaluate the qualitative orientation of its message.

For the content analysis we started from the following research question: Is the message of the film favourable or unfavourable to Romanian migrants? In order to do this, we devised a scale to take account of the following categories in the depiction: time, place (RO/UK), lawfulness (legal/illegal), orientation of the message (5-point Likert from strongly negative to strongly positive), and motto (each scene ends with a motto-like conclusion presented in the narrator's voice). The time, place and lawfulness are straightforward to score, without any subjective uncertainties. We were careful to analyse the orientation of the message of each individual sequence without cross-reference to the context, in order to avoid being subjectively influenced by any perception of the film as a whole. We chose to use a 5-point scale with a neutral middle point because some scenes lack any connotations (pro/contra). The mottos arise almost by default from the narrative flow of the film, as conclusions presented in the voiceover or even by the protagonists. At the same time, we decided to carry out, with a group of 100 students, a two-item interview after they had viewed the film. These questions concerned their perceptions of the message: Q1 How did you receive the film? Q2 Which character impressed you the most.? Respondents were asked to write short free-form answers to these questions. Analysis and interpretation of the answers allowed us to assign each respondent reaction to one of three classes: positive, neutral or negative.

\section{Results}

The three-part documentary "The Romanians Are Coming” presents seven Romanians trying to find jobs in the UK. Very briefly, their stories are:

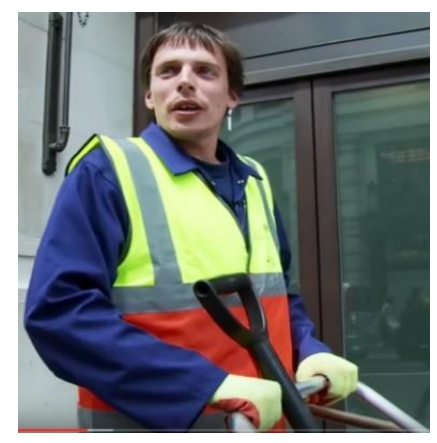

Alex from Canada (episodes 1- 3)

Arrives in the UK after having problems with the tax authorities in Canada;

$>$ In Canada he has parents, had a business, wife, house and car;

During the film he finds four jobs but loses them due to his drink problem;

$>$ Respects the law;

Fluctuating roles: a "good Samaritan" to - a streetwise waster;

Hopes to get a decent job and to be able to rent a flat. 

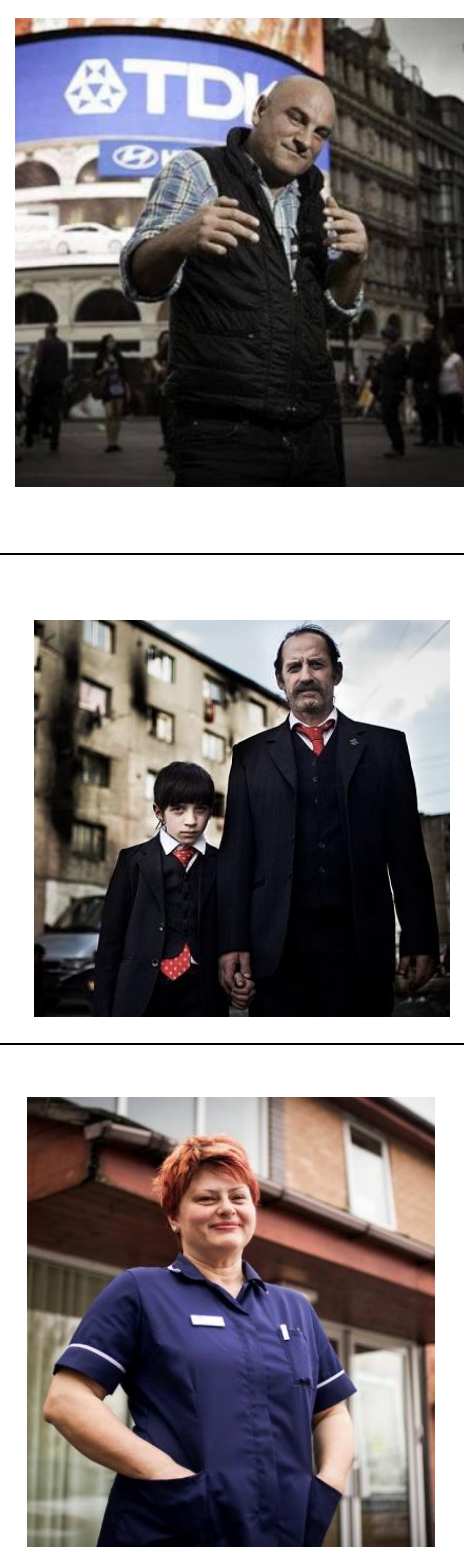

Mihaela from Constanța (episode 2) - Nurse in Constanta, with very good living conditions, goes to the UK to work in her profession, but is disappointed by the housing provided and returns home after a month;

$>$ Has a job acquired through a placement agency;

The reality she meets differs from the image presented by the recruitment agency;

$>$ The housing conditions are significantly worse than those at home;

Family break-up contributes to her decision to quit after one month.

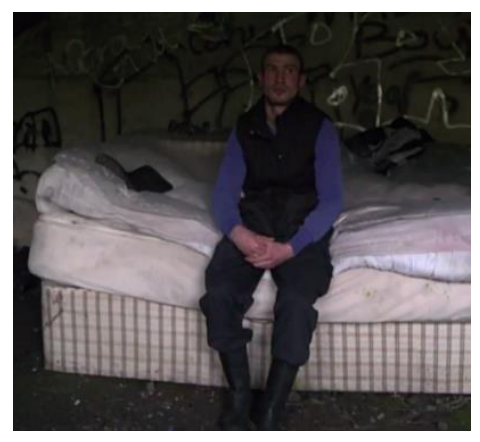

Adi from Lupeni (episode 2) - established in the UK for 6 years. Works at a car wash (earning $£ 180$ per week) and sleeps under a bridge in order to send as much money home as possible;

$>$ His wife and mother have stayed in Lupeni along with his five siblings;

$>$ Lives in miserable conditions under a bridge;

$>$ Visits home once a year;

$>$ His family do not know about his living conditions;

$>$ Wants to rent a house so that he can bring his wife to the UK 


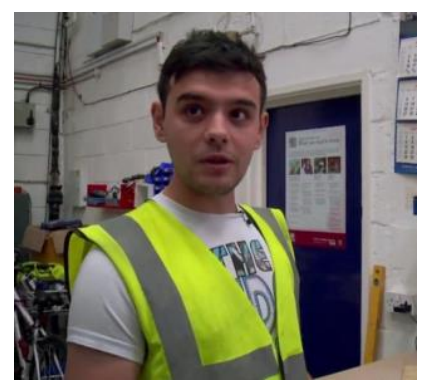

Cosmin from Oraviţa (episode 3) - comes to the UK where he already has two friends settled. Comes to the UK because all his friends have left Oravita;

$>$ Lives with two friends who have a rented house;

$>$ Finds a job in a warehouse after 20 minutes of Internet search - starts at 6 am and earns $£ 6.50$ an hour (there are no British employees at the warehouse);

In 10 years' time he sees himself settled in the UK, married with two children and a Range Rover.

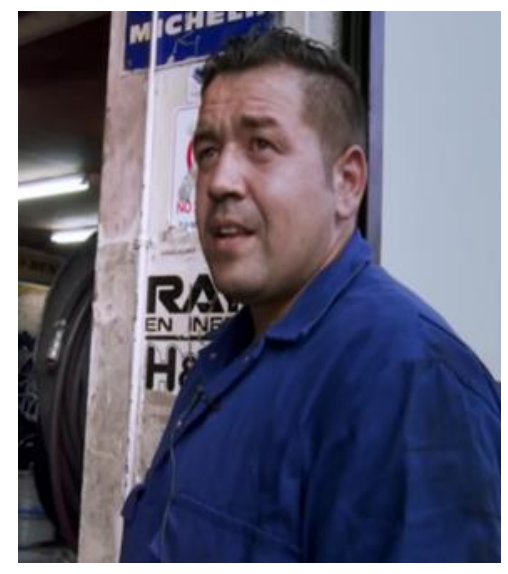

Alex Fekete - from Pata Rat, Cluj (episodes 1-3) - the narrator's voice in English. Reaches the UK, finds work in a tyre fitting bay, highly appreciated by his boss and colleagues, but then decides to return home.

Alex Fekete, the narrator, lives near the rubbish disposal site in Cluj, where social housing for Roma has been built;

$>$ Arrives in the UK, gets a job he is experienced in, works so well that his boss decides to even pay him for his probation period ( $£ 200 / 4$ days);

$>$ Feels conflicted about the prospect of bringing his wife and child to the UK and breaking away from the Roma community;

Although he has real prospects of success in the UK, he decides to return home.

The story is presented by each character and also by Alex Fekete (a Romanian Roma from Cluj Napoca) in English as narrator. Of the seven stories only two are connected with Roma people (Sandu's and Alex Fekete's). The stories have different lengths, from 5 minutes and 48 seconds in seven scenes about Adi from Lupeni, to 32 minutes and 10 seconds in 21 scenes about Alex from Canada. The film was made mainly in the UK, but around one-third in Romania (Figure 1):

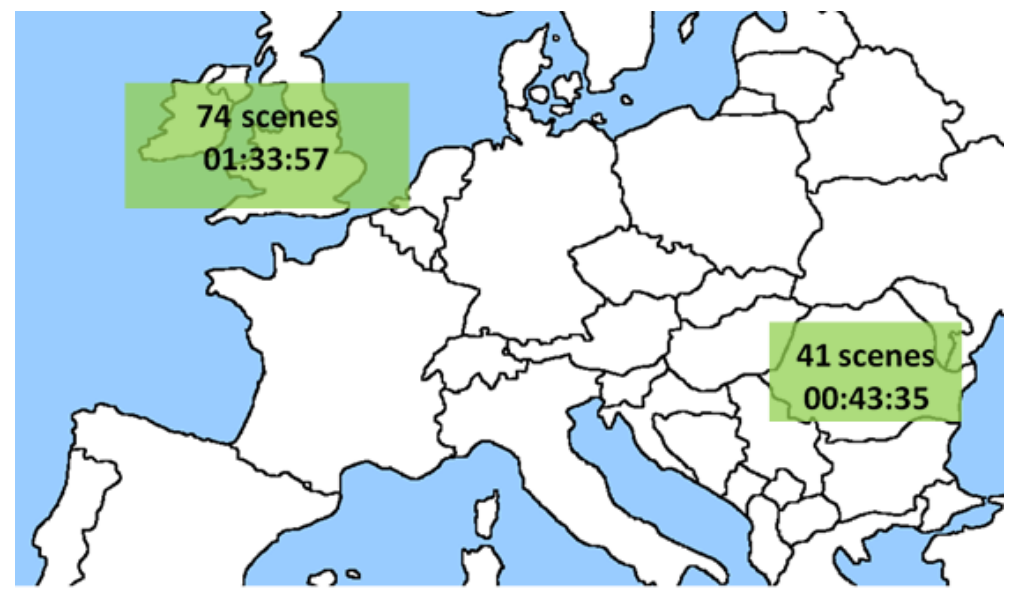

Figure 1. The place of filming 
Almost the entire content of the documentary consists of episodes showing entirely legal activities. Only a very small proportion of the documentary depicts unlawful activity, as it is presented in the Figure 2:

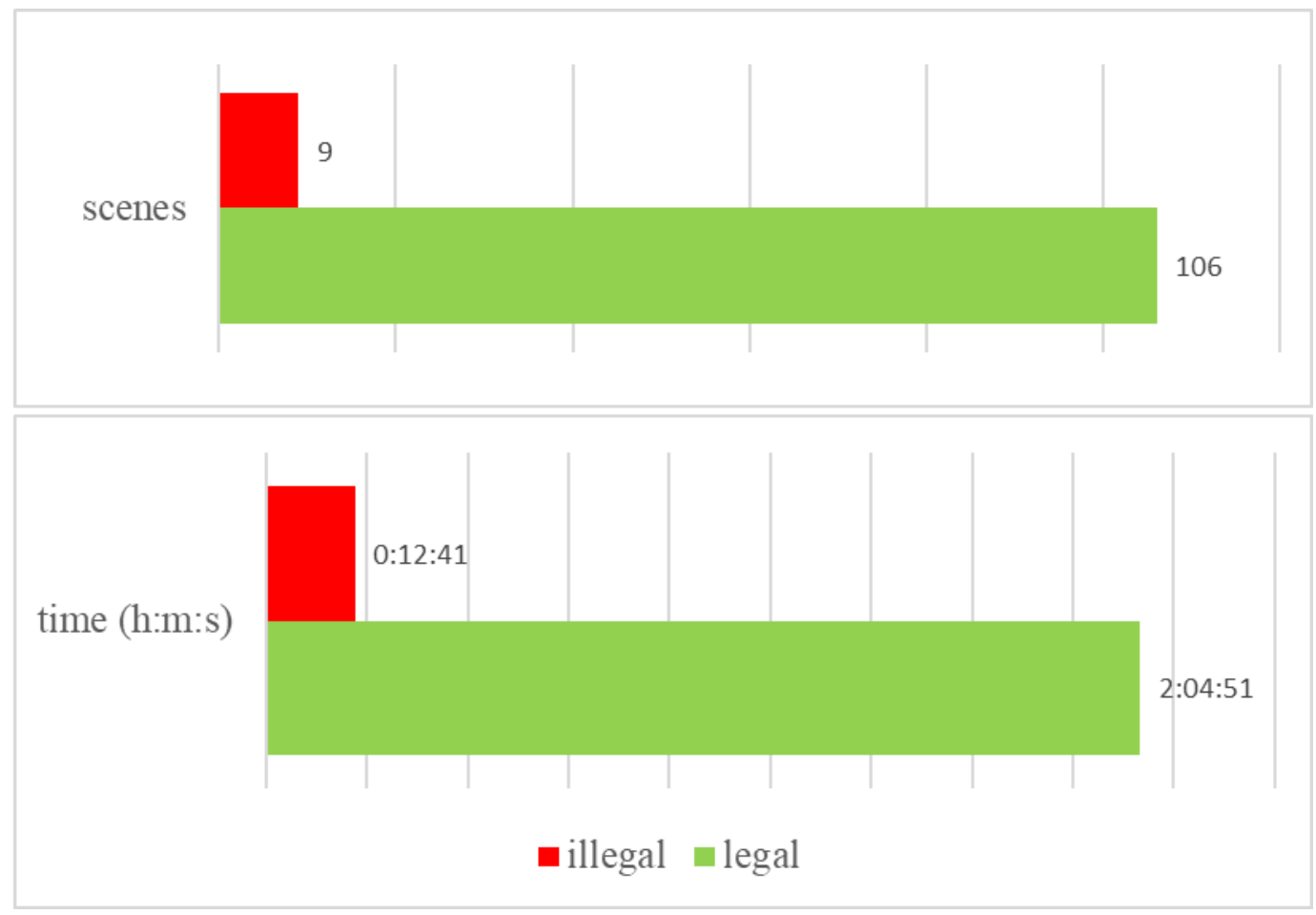

Figure 2. Legal vs. Illegal scenes into the documentary

We made an evaluation of the episodes and assigned each to a descriptive category depending on its place on a subjective five-point interval scale ranging from strongly negative to strongly positive. The cumulative duration of the negative message scenes was 34 minutes, compared with almost 54 cumulative minutes of discernibly positive message content, as is shown into the Figure 3 (hh:mm:ss).

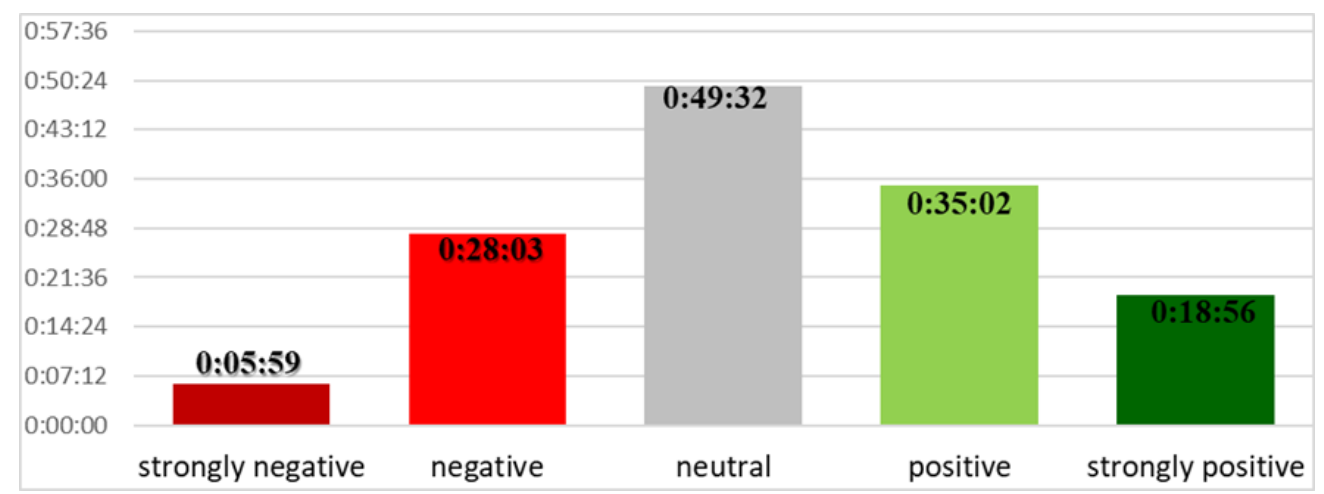

Figure 3. The negative vs. positive scenes

The correlation of the type of message with the place of filming is presented into the Figure 4: 


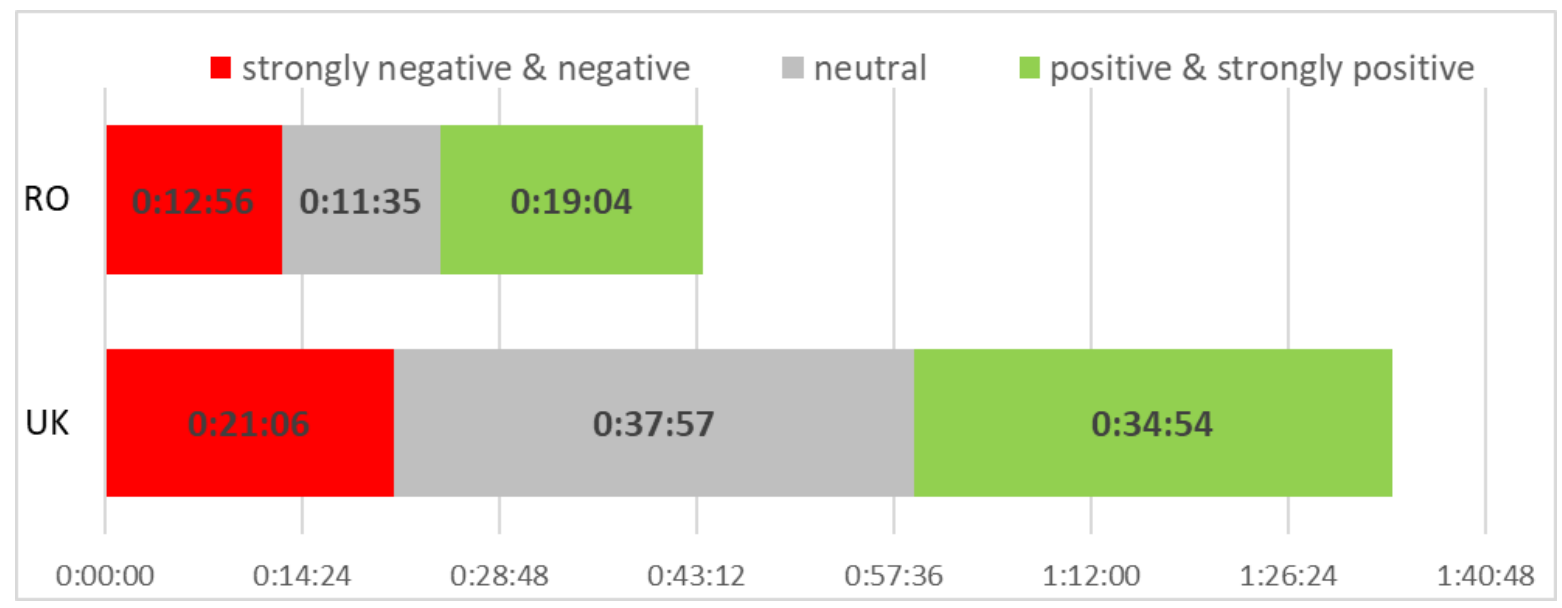

Figure 4. The negative vs. positive scenes correlated with the place of filming

We treated as strongly negative or negative messages those that were accompanied by images of extreme poverty (poor living conditions in Romania, or - for example - Romanian incomers sleeping on the streets in the UK). The most relevant mottos for the strongly negative sequences noted were:

$\checkmark$ In these days, you know, people are planning to go to Mars and we are still riding horses. That's the difference between nations.

$\checkmark$ Last year 22,000 people are coming in UK for a job, and most of them are best qualification man and women. But I don't want to be lying you, there are also some Romanians with no jobs and nowhere to live. (...) When I see beggars on the streets, I'm ashamed to be a gipsy. These guys should be sent back home.

$\checkmark$ This country [RO] is very poor.

$\checkmark$ Not everywhere in Ro is $f^{* * *}$ ed-up like the gipsy ghetto in Baia Mare. And a 58year-old gipsy like Sandu will never get a job here.

The most relevant mottos for the strongly positive sequences were:

$\checkmark$ For me, this job is my life! England is for me...o gradina lasata de la Dumnezeu si trebuie facut curatenie tot timpul! [a garden given by God and so it must be cleaned all the time]

$\checkmark$ We Romanians are the hardest workers in Europe. Some of us have to fight for everything.

$\checkmark$ Locals do not want to work in such warehouses.

$\checkmark$ I never worked anywhere so fantastic. And they want for me to stay.

$\checkmark$ I feel like I'm cutting in two: if I bring my family to England, I turn my back to my people.

The film was shown to several groups of students (of Anthropology, Sociology and Psychology) (N=100) during the academic year 2017-2018 and they were asked to write a short feedback about their perceptions of the film. The distribution of their answers is presented below (\%): 
negative neutral positive

Figure 5. The students' perceptions of the film

\section{Discussion}

The Romanians Are Coming is a documentary with a clearly positive overall message about Romanians. Of the seven stories focused on, only two are about the Roma and three are connected with extreme poverty. The public reaction of Romanian public figures and of the Romanian mass media to the broadcasting of this documentary was almost entirely negative. The feedback recorded from the 100 students in our sample after they had seen the film was negative in over $50 \%$ of cases. Their main arguments for this reaction could be summarised as follows: the documentary is about poor Roma and we are not Roma, neither are we that poor. The five non-Roma stories were completely ignored by these respondents. We found that even when, in follow-up discussions, we drew attention to the four "non-poor" stories, they were resistant to modifying their perception. The strength of this resistance suggests that their nonreceptiveness to the objective content was conditioned by definite, if tacit, negative presuppositions.

The phrasing of the title projects an obviously threatening, invasion-evoking subtext: the Romanians, the strangers, the danger, the massive social problems ... are coming! For a Romanian audience in Romania, this title is received as showing something about how people abroad see us. There have indeed been many cases of émigré Romanians having problems with the law. For such receivers, in a domestic audience, the film title itself is sufficient, even on first encounter, to activate their stereotype that those "other" people in western Europe do not have a positive image of "us". They treat us as a potential danger, as poverty-stricken, and as uneducated. Yet in many cases we are not. Even before they have found any examples of such stereotyping in the documentary itself, Romanian receivers are prone to allow the title to trigger a kind of personal stereotype of their own - one of how foreigners perceive Romanians. With this activated filter in their minds, the subsequent content of the film is in fact almost completely ignored.

\section{Conclusions}

Pettigrew (1998: 70), in discussing intergroup contact theory, presents four processes of change: learning about the outgroup, changing behaviour, generating affective ties, and ingroup reappraisal. The documentary The Romanians Are Coming arguably aims to promote all these processes. This intention, however, would seem to be frustrated by the strength of what we could informally call a Romanian "inferiority complex" which is too readily supported by embarrassing anecdotes about Romanians behaving badly abroad. A surprising feature of our findings is that a relatively sophisticated, young and well-educated sample of viewers should have had such a negative response to the film series. This may tell us something about the way that stereotypes, even stereotypes of presumed stereotyping behaviour, operate at an affective level rather than a rational one. 
Acknowledgments: The author gratefully acknowledge the contributions of Dorothy and Stuart Elford, of Timișoara, in helping to refine the English expression and presentation of the content and for their academic criticism, which has improved the clarity of the argument.

\section{REFERENCES}

Appel, Markus, and Kronberger, Nicole. 2012. Stereotypes and the Achievement Gap: Stereotype Threat Prior to Test Taking, Springer LLC

Bigler Rebecca, and Liben Lynn. 2006. A Developmental Intergroup Theory of Social Stereotypes and Prejudices in Kail R. ed. Child Development and Behaviour, Elsevier.

Blair Irene. 2002. The Malleability of Automatic Stereotypes and Prejudice, Personality and Social Psychology Review, vol. 6, No.3, 242-261

Bluemel James. 2015. The Romanians Are Coming, online documentary available at https://www.channel4.com/programmes/the-romanians-are-coming

Esses Victoria, Haddock Geoffrey, Zanna Mark. 1993. Values, stereotypes, and emotions as determinant of intergroup attitudes in Mackie DM\&Hamilton DL eds. (1993) Affect, Cognition, and Stereotyping: Interactive Processes in Group Perception, San Diego: Academic

Goffman, Erving. 1963. Stigma, Prentice Hall: Englewood Cliffs

Grubb, Edward, and Hupp, Gregg. 1968. Perception of Self, Generalized Stereotypes, and Brand Selection, Journal of Marketing Research, Vol. V.

Hilton, James \& Hippel von, William. 1996. Stereotypes, in Annual Review of Psychology, 47, 237-271

Jussim Lee, Crawford Jarret and Rubinstein Rachel. 2015. Stereotype (In)Accuracy in Perceptions of Groups and Individuals, Current Directions in Psychological Science, Vol. 24(6), 490-497

Link Bruce, and Phelan Jo. 2001. Conceptualizing Stigma, Annual Review of Sociology, 27, 363-85

Pettigrew, Thomas. 1998. Intergroup Contact Theory, Annual Review of Psychology, 49, 65-85

Ruscher Janet. 1998. Prejudice and stereotyping in everyday communication, in Advances in Experimental Social Psychology, vol.30, 0067-2601/98

Spencer S., Logel C. and Davies P. 2016. Stereotype Threat in Annual Review of Psychology, 2016, 415-437

Stangor Charles and Lange James. 1994. Mental Representations of Social Groups: Advances in Understanding Stereotypes and Stereotyping. Advances in Experimental Social Psychology Vol. 26, Academic Press.

*** Channel 4, felicitat de ONG-uri romanesti pentru "Vin romanii": Cei care critica, ignoranti sau ipocriti [Channel 4 congratulated by Romanian NGOs for "The Romanians are Coming": those who criticise are ignorant or hypocritical] ziare.com available at http://www.ziare.com/diaspora/romani-mareabritanie/channel-4-felicitat-de-ong-uri-romanesti-pentru-vin-romanii-cei-care-critica-ignoranti-siipocriti-1351181. 